\title{
OKOLICZNOŚCI KOMPOZYCJI HYMNU AKATYST KU CZCI NAJŚWIECTSZEJ MARYI PANNY
}

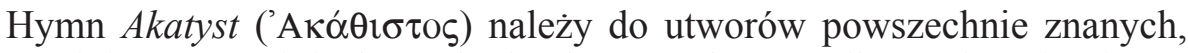
szczególnie w Kościołach wschodnich. W Polsce rzadko wykonuje się go $\mathrm{w}$ kościele, ale jest dostępny $\mathrm{w}$ internecie $\mathrm{w}$ rożnych wykonaniach i w różnych językach.

Muzyka jest zapewne tak dawna jak ludzie na ziemi. Można ją dzielić na różne typy i rodzaje. W muzyce wokalnej wyróżniamy pieśni świeckie, religijne, wojenne, laudacyjne, obrzędowe (ślub, pogrzeb), pieśni funkcyjne, np. rolników, rybaków, kobiet tkających, itp. W muzyce religijnej znane są pieśni obrzędowe (liturgiczne, kultowe), pieśni religijne niezwiązane wprost w kultem, pieśni dziękczynne, błagalne; pieśni wyrażające wiarę, pobożność, pieśni niosące określone treści teologiczne (z założenia lub pośrednio) ${ }^{1}$. Liczne były pieśni proste (krótkie), pieśni bardziej rozwinięte (hymny); pieśni śpiewane indywidualnie, pieśni śpiewane chóralnie (zbiorowo). Największy rozkwit chóralnej pieśni przypada na przełom VI i V w. przed Chrystusem². Działali wtedy w Grecji słynni kompozytorzy, jak: Simonides, Bakchilides i Pindar. Są pieśni „budujące”, wzniosłe (świeckie czy religijne); są pieśni ludowe, młodzieżowe; są piosenki nieprzyzwoite (hultajskie). Ślady takich piosenek znajdujemy nawet w Biblii (np. Iz 23, 15-17). Bardzo interesująca jest kwestia melodii, roli instrumentów, rymu, rytmu, tzw. metrum, co pozwala dzielić utwory muzyczne na różne grupy i typy, rodzaje, a także sytuować je w czasie czy przestrzeni. Już w Grecji archaicznej posługiwano się wieloma instrumentami, posiadano też różne skale muzyczne (tonacje), np. dorycką, frygijską, lidyjską̧.

Celem niniejszego artykułu jest przybliżenie polskim czytelnikom słynne-

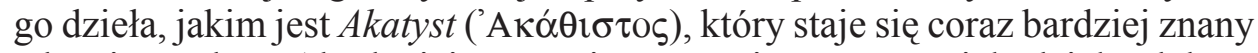
także i w Polsce. Aby lepiej zrozumieć, czym jest to wspaniałe dzieło, dobrze będzie usytuować je w kontekście historycznym, gdyż zanim pojawiło się ono

* Ks. dr hab. Józef Grzywaczewski, prof. UKSW - profesor nadzwyczajny w Katedrze Teologii Patrystycznej w Instytucie Teologii Systematycznej na Wydziale Teologicznym Uniwersytetu Kard. Stefana Wyszyńskiegow Warszawie; e-mail: j.grivalles@gmail.com.

${ }^{1}$ Por. K. Kumaniecki, Historia kultury starożytnej Grecji i Rzymu, Warszawa 1967, 105.

${ }^{2}$ Por. tamże, s. 106.

${ }^{3}$ Por. tamże, s. 103. 
w Grecji w VI czy VII w., istniała długa tradycja w zakresie poezji, muzyki i hymnografii, tak w Izraelu, jak i w innych krajach wokół Morza Śródziemnego. W tym sensie Akatyst, chociaż jest utworem oryginalnym, wyrasta z tradycji wieków i w pewnym sensie jest jej owocem. Podobnie, zanim Adam Mickiewicz i Juliusz Słowacki zaczęli pisać swe poematy, istniała w Polsce długa tradycja literacka. W tradycję muzyczną, istniejącą od kilku wieków, wpisują się kompozycje Fryderyka Chopina czy Stanisława Moniuszki.

W krajach o tradycji wschodniej istnieją prace na temat hymnu 'Aкó $\theta \imath \sigma \tau o \varsigma$. Mały zarys bibliografii podaje Andrzej Bober ${ }^{4}$. Encyklopedia Katolicka nie podaje żadnych publikacji po polsku na temat $A k a t y s t u^{5}$, co zdaje się oznaczać, że w dawniejszych czasach nie prowadzono w Polsce badań naukowych nad tym utworem. Obecnie poszczególni autorzy raczej nawiązują do tego hymnu w pracach na temat śpiewu kościelnego oraz greckich hymnów okresu post-patrystycznego.

Zajmujący się Akatystem ma do dyspozycji opracowania w językach zachodnich. Sa to: G.G. Meersseman, Der Hymn Akathistos im Abendland, Freiburg 1958; E. Wellesz, A History of Byzantine Music and Hymnography, Oxford 1949, 1962²; J. Vereecken, L'hymne Acathiste, Icône chantée et le mystère de l'Incarnation en nombres, „Byzantion” 63 (1993) 357-387; F. Jeanlin, Citations et thèmes bibliques dans l'hymn Acathiste (byzantine) à la Mère de Dieu, w: La Liturgie interprète de l'Ecriture, red. C. Braga - A. Pistoia, Paris 2002, 89-103. Ważnym opracowaniem współczesnym na temat Akatystu jest praca: L.M. Peltomaa, The Image of the Virgin Mary in the Akathistos Hymn, Brill Leiden - Boston - Köln 2001 (tam jest bibliografia, s. 2017-2030). Jest to, być może, pierwsza próba przedstawienia stanu badań na temat Akatystu. Autorka stwierdza, że jak dotąd, brakuje całościowej analizy teologicznej; wcześniejsze zaś prace dotyczą zagadnień wybranych ${ }^{6}$. Ten brak można uznać za uzupełniony przez książkę E.M. Toniolo, Akathistos. Inno alla Madre di Dio. Edizione metrica. Mistagogia, Commento al testo, Roma 2017. Obok tekstu greckiego cenny jest tam komentarz do poszczególnych strof hymnu (s. 145-344) ${ }^{7}$.

\footnotetext{
${ }^{4}$ Por. AP, s. 513.

${ }^{5}$ Por. R. Niparko, Akathistos, EK I 225.

${ }^{6}$ Por. L.M. Peltomaa, The Image of the Virgin Mary in the Akathistos Hymn, Brill - Leiden - Boston - Köln 2001, 23: „It is astonishing that that no complete analysis of its content has ever been made”.

${ }^{7}$ Inne opracowania bezpośrednio lub pośrednio dotyczące Akatystu w układzie alfabetycznym: A. Baumstark, Chairetismos, RACh II 993-1006; J. Buxakowski, Najświętsza Panna w Liturgii, w: Gratia Plena. Studia teologiczne o Bogurodzicy, red. B. Przybylski, Poznań - Warszawa - Lublin 1965, 79-128; A. Cameron, The Theotokos in Sixth Century Constantinople, JTS 29 (1978) 79108; K.F. Felmy, Die Gottesmutter in den Hymnen der Orthodoxen Kirche, OKS 45 (1996) 97-115; J. Grzywaczewski, Saint Ambrose as a Defender of the Christian Faith in the Greek Hymnography, VoxP 28 (2008) t. 52/1, 281-289; tenże, Wstęp, w: Wschód Zachodowi. Greckie hymny ku czci łacińskiego biskupa Ambrożego z Mediolanu, tłum. G. Jaśkiewicz, Lublin 2012, 9-18; J.S. Gajek, Akatyst ku czci Bogurodzicy, w: Cześć Maryi, red. W. Beinert, Warszawa 1992, 315-321; A. Klawek, Biblijne symbole maryjne, RBL 10 (1956) 216-227; M. Starowieyjski, Mariologia św. Atanazego, RTK
} 
Akatyst jako hymn chrześcijański w języku greckim wyrasta z kilku tradycji, jak: hymnografia biblijna Starego Testamentu; muzyka i hymnografia antyczna, głównie helleńska; hymnografia chrześcijańska, od hymnów w Nowym Testamencie poczynając; a przede wszystkim mariologia, czyli to, co zostało napisane na temat w Maryi w okresie patrystycznym. Podejmujemy próbę usytuowania Akatystu jako utworu literackiego o charakterze kultowym (liturgicznym) w szerokim kontekście historycznym, nie podejmujemy natomiast kwestii artystycznych, jak metrum czy melodia. Tego rodzaju ogólna prezentacja może ułatwić czytelnikom zrozumienie hymnu, a może stać się także zachętą do dalszych studiów w tej dziedzinie.

1. Hymnografia Starego Testamentu. Dla naszego zagadnienia cennym zabytkiem hymnograficznym w okresie Starego Testamentu są pieśni biblijne. Ich przykładem może być pieśń dziękczynna, jaką zaśpiewali Izraelici po przejściu przez morze (Morze Czerwone). W Księdze Wyjścia czytamy: „Wtedy Mojżesz i synowie Izraela razem z nim zaśpiewali taką pieśń: Będę śpiewał ku czci Jahwe, który wspaniale są potęgę okazał, gdy konia i jego jeźdźca pogrążył w morzu [...]. Wyborowi jego wodzowie zginęli w Morzu Czerwonym” (15, 1 i 4; całość: 1-19) ${ }^{8}$. Po nim następuje pieśń kobiet: „Miriam prorokini, siostra Aarona, wzięła bębenek do ręki, a wszystkie kobiety szły za nią w pląsach i uderzały w bębenki. A Miriam przyśpiewywała im: Śpiewajmy pieśn chwały na cześć Jahwe, bo swą potęgę okazał, gdy konie i jeźdźców ich pogrążył w morzu" (Wj 15, 20). Jej śpiew uznano za natchniony9.

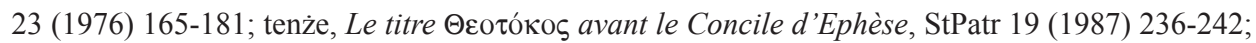
J. Szöverffy, A Guide to Byzantine Hymnography, t. 1-2, Brooklyn - Leyden 1978; E.M. Toniolo, Akathistos. Saggi di critica e di theologia, Roma 2000; tenże, L'inno Acatisto, monumento di teologia e di culto mariano nella Chiesa bizantina, w: Pontificia Academia Mariana Internationalis, De cultu mariano saeculis VI-XI, vol. 4, Roma 1972, 1-39; E. Wellesz, The Akathistos. A Study in Byzantine Hymnography, DOP 9-10 (1956) 143-174; A. Wilson-Dickson, Historia muzyki chrześcijańskiej, thum. M. Wiśniewska, Warszawa 2007.

${ }^{8}$ Nie wszyscy historycy i bibliści są zdania, że Izraelici przeszli przez Morze Czerwone. Przypuszcza się, że mogli przejść raczej przez cieśninę Akaba nad Morzem Śródziemnym, a potem szli wzdłuż Morza Czerwonego. Zob. The Oxford Bible Commentary, ed. J. Barton - J. Muddiman, Oxford 2001, 76: „They went inland «by way of the wilderness toward the Red Sea». In other places (23:31; Num 21:4; I Kings 9:26) «the Red Sea» (Heb. Sea of reeds, Leeds) refers to the Gulf of Aquaba. It is often thought that the Gulf of Suez is meant here, or one of the lake north of it". W ten sposób wyznaczają trasę Izraelitów wydawcy La Bible TOB (Paris 1994, w aneksie na końcu mapa II). W ten sposób wyznaczają też trasę wydawcy Catholic Good News Bible (Collins Bible Society 1994, w aneksie na początku mapa II). W Księdze Wyjścia powiedziane jest, że Izraelici znajdowali się ,pod Pi-Hahirot naprzeciw Baal-Sefon” (Wj 14, 9), a ta miejscowość znajduje się nad Morzem Śródziemnym. Dopiero po kilku dniach przybyli do Elim (Wj 15, 27), a ta miejscowość znajduje się powyżej Morza Czerwonego. Nad to morze przyszli później i szli w dół, po czym skręcili w lewo w głąb lądu w kierunku Synaj. Taką trasę zdaje się potwierdzać opis w Lb 33, 1-49.

${ }^{9}$ Por. The Oxford Bible Commentary, s. 77: „Miriam is called a prophet probably because of this song, which is seen as inspired". 
Są też w Biblii inne pieśni: „Śpiewali wtedy Izraelici pieśń następującą: Tryskaj źródło, opiewajcie je. Studnia, którą kopali książęta i naczelnicy ludu drążyli berłem i swymi laskami” (Wj 21, 17-18). Tak śpiewali Izraelici przy studni Beer (Lb 21, 16). Śpiewano też po zajęciu kraju Amorytów i Moabitów: „Dlatego śpiewali pieśniarze: Idzie do Cheszbonu. Niech będzie odbudowane miasto Sichona" (Lb 21, 27; całość: 27-30). Godny uwagi jest tzw. Hymn Mojżesza (Pnp 32, 1-44). Zaczyna się od słów: „Uważajcie niebiosa na to, co powiem, słów moich słuchaj, ziemio" (Pnp 21, 1).

Najcenniejszym zabytkiem hymnografii izraelskiej są psalmy. Wyrażają one wiarę, pobożność i duchowość Izraelitów, zawierają liczne elementy doktrynalne. Pochodzą one z różnych okresów ${ }^{10}$. Dostrzega się w nich kunszt literacki ich twórców. W niektórych psalmach można zauważyć podobieństwa do pieśni i hymnów innych krajów, szczególnie Egiptu. Na przykład uczeni wskazują na podobieństwa Psalmu 104 do hymnu ku czci boga Atona. Psalm 137 nawiązuje wprost do pobytu Izraelitów w Babilonii: „Nad rzekami Babilonu tam myśmy siedzieli i płakali, kiedyśmy wspominali Syjon” (Ps 137[136], 1).

Psalmy śpiewano przy różnych okazjach, głównie jednak były to pieśni kultowe. Spiewano je w świątyni, także podczas liturgii domowej (np. wieczerzy paschalnej), podobnie jak u katolików śpiewa się kolędy podczas wieczerzy wigilijnej. Spiewano psalmy w synagogach i odczytywano odpowiednie fragmenty Pisma Świętego. Śpiewy synagogalne stały się wzorem dla młodych wspólnot chrześcijańskich, szczególnie wśród ludności pochodzenia żydowskiego (judeochrześcijanie). Melodie raczej nie były podobne do naszych, gdyż nie były zbudowane na skali ośmiotonowej (jak to jest obecnie). Wiele jest w Starym Testamencie informacji o śpiewie, śpiewakach i instrumentach $^{11}$. Skrót wiadomości na tematy muzyczne, głównie na temat instrumentów, stanowi Psalm 150. Czytamy tam: „Chwalcie Boga w Jego świątyni [...]. Chwalcie Go dźwiękiem rogu, chwalcie Go na harfie i cytrze! Chwalcie Go bębnem i tańcem, chwalcie Go na strunach i flecie! Chwalcie Go na cymbałach dźwięcznych, chwalcie Go na cymbałach brzęczących: Wszystko, co żyje, niech chwali Pana!”. Jak widać, grano na rogu, harfie, cytrze, bębnie, cymbałach, na flecie, a także na innych instrumentach, których tu nie wymieniono.

2. Muzyka i śpiew w tradycji helleńskiej. Na śpiew młodego Kościoła miały wpływ antyczne tradycje muzyczne. Muzyka w ogóle, w tym hymnografia, była bardzo rozwinięta w kulturze greckiej od najdawniejszych czasów. Znane są przede wszystkim dwa główne typy hymnów greckich: homeryckie

${ }^{10}$ Por. The Oxford Dictionary of the Christian Church, red. L.F. Cross - E.A. Livingstone, Oxford 1997, 1343: „Most modern scholars believe that that the Psalms come from a variety of authors and are of widely differing dates".

${ }^{11}$ Por. R. Rachuta, Muzyka w Biblii, praca doktorska pod kierunkiem K. Ilskiego, miejsce i data nie są podane, pełny tekst: https:/repozytorium.amu, edu.pl.../1Praca\%doktorska20\%Robert\%20 Rachuta.pdf (dostęp 10.02.2018). 
oraz orfickie. Nie wydaje się, aby autorzy hymnów ku czci Matki Bożej nawiązywali wprost do hymnów antycznych, ale fakt, że żyli i tworzyli w kraju, w którym od kilkunastu wieków komponowano i wykonywano różne hymny, mógł mieć wpływ na kompozytorów i poetów chrześcijańskich, nawet, jeśli nie byli oni tego zupełnie świadomi ${ }^{12}$. Hymny greckie są dostępne $\mathrm{w}$ języku polskim w odpowiednich wydaniach książkowych oraz w internecie. Zasygnalizujemy szczególnie te, które adresowane są do bóstw helleńskich.

a) Hymny homeryckie. Hymny do Zeusa i Hery, Hymny do Ateny, Hymny do Apollona i Muz, Hymn do Hermesa, Hymn do Aresa, Hymny do Afrodyty, Hymn do Posejdona, Hymn do Hefajstosa, Hymn do Matki bogów, Hymn do Artemidy, Hymn do Demeter, Hymn do Hestii, Hymn do Heliosa, Hymn do Selene, Hymn do Dionizosa, Hymn do Heraklesa o lwim sercu, Hymn do Asklepiosa, Hymn do Dioskurów ${ }^{13}$.

b) Hymny orfickie. Zachował się powstały w II lub III w. anonimowy zbiór hymnów religijnych. Przypuszcza się, iż były dziełem jednego autora (Orfeusza). Powstałe prawdopodobnie w Azji Mniejszej utwory zostały przekazane w rękopisach wspólnie z Hymnami homeryckimi oraz hymnami Kallimacha i Proklosa. Zbiór obejmuje 87 krótkich pieśni religijnych, poprzedzonych wstępem adresowanym do Muzajosa. Hymny te, mające w większości formę litanii, adresowane są do poszczególnych bóstw greckich. Wymieniamy niektóre z nich: Orfeusz do Muzajosa, Do Nocy, Do Uranosa, Do Protogonosa, Do Gwiazd, Na Heliosa, Hymn Pana, Hymn Heraklesa, Hymn Kronosa, Hymn Rei, Hymn Zeusa, Hymn Hery, Hymn Posejdona, Do Plutona, Hymn Zeusa pana piorunów, Hymn do Zeusa, Hymn, Morza, Hymn Gai, Hymn Persefony, Hymn Dionizosa ${ }^{14}$, Hymn Ateny, Hymn do Nike, Hymn Kuretów, Hymn Leto, Hymn Artemidy, Hymn Tytanów, Hymn Korybanta, Hymn Demeter Eleuzyńskiej, Hymn Hor, Hymn Semele, Hymn Nimf, Hymn Hermesa Chthoniosa, Hymn Erosa, Hymn Charyt, Hymn do Nomosu, Hymn Aresa, Hymn Hefajstosa, Hymn Asklepiosa, Hymn Hygiei, Hymn Erynii, Hymn Eumenid, Hymn Okeanosa, Hymn Hestii, Hymn Hypnosa ${ }^{15}$.

Dla naszego tematu na uwagę zasługują także hymny antyczne do bogiń pogańskich. Przytoczymy kilka fragmentów.

${ }^{12}$ Por. E. Wellesz, History of Byzantine Music and Hymnography, Oxford 1962, 96-97: „It is a well-known fact that the revival of Platonism in the second century, the so-called Middle Platonism, facilitated the entry of Christianity into the world of Graeco-Roman civilization. Platonic musical theory could be adapted without difficulty to the teaching of the theologians, as will be shown in the next chapter. The connection between Greek philosophy and Christian ideal of music becomes even closer under the influence of Neoplatonism".

${ }^{13}$ Tekst grecki i polski: panteon.pl/Hymny-homeryckie.

${ }^{14}$ Por. Kumaniecki, Historia kultury, s. 111: „Dionizos nie był dla orfików jedynie bogiem wina, lecz siłą wypełniającą wszechświat i jego twórcą. System orfików był więc systemem teologicznym. [...] Najwyższy rozwój orfizmu przypada na wiek VI”.

${ }^{15}$ Tekst grecki i polski: pantheon.pl/Hymny-do-Bogow-hellenskich\#orfickie. Tytuły hymnów nie są sformułowane w ten sam sposób; podajemy je tak, jak są one napisane na wskazanej stronie internetowej. 


\section{Z homeryckiego Hymnu II do bogini Ateny:}

„Pallas Atenę, sławną boginię, zaczynam opiewać [...], miast opiekunkę,

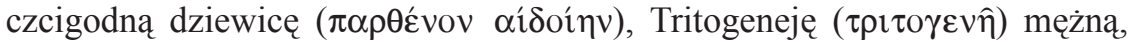
którą urodził Dzeus samojeden [...]. Bądź pozdrowiona ( $\chi \alpha \hat{\imath} \rho \varepsilon$ ), córko ty Zeusa, co dzierży egidę"16.

Określenie „dziewica” ( $\pi \alpha \rho \theta$ ćvoऽ) stosowane jest w odniesieniu do Maryi, tak w Nowym Testamencie ${ }^{17}$, jak i w pismach autorów chrześcijańskich. Po-

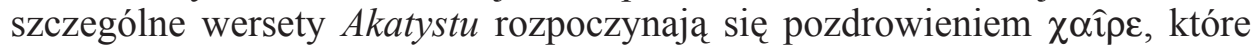
jest thumaczone jako „raduj się” oraz „bądź pozdrowiona”.

Z orfickiego Hymnu Artemidy (36): „Wysłuchaj mnie, o Królowo ( $\beta \alpha \sigma i ́$ $\lambda \varepsilon 1 \alpha$ ), wieloimienna córo Zeusa" ${ }^{18}$. Wiadomo, że w piśmiennictwie chrześcijańskim określa się Maryję jako Królową. Autor określa Artemidę jako wieloimienną ( $\pi \circ \lambda v \omega ́ v v \mu \varepsilon)$; od najdawniejszych czasów chrześcijanie sławią Maryję określając Ją różnymi tytułami (imionami); w Akatyście jest 144 określeń Maryi.

Niezależnie od poszczególnych zwrotów i terminów, hymny ku czci bogiń helleńskich mogły stanowić dla poetów chrześcijańskich swego rodzaju model czy wzór od strony czysto formalnej. Przytoczymy jeden z hymnów do bogini Demeter:

„Deo, bogini wierna Matko, wieloimienne bóstwo,

Boska Demeter, wychowująca dzielną młodzież, dawczyni rozkoszy,

Dająca bogactwo bogini, żywicielko kłosów, dająca wszystko,

Ciesząca się pokojem i znojną pracą [w polu],

Opiekunko zasiewów i gleby, dawczyni stogów zboża i zielonych plonów,

Która zamieszkujesz święte sześcienne [mury] Eleuzis,

Powabna, ukochana, żywicielko wszystkich śmiertelnych,

Która pierwsza zaprzęgłaś woły w wędzidło rolnika

I uczyniłaś życie śmiertelnych dostatnim i bardzo szczęśliwym,

Wzmagająca wzrost, współdomowniczko Bromiosa, wspaniale uczczona,

Niosąca pochodnię, nieskalana, ciesząca się letnimi żniwami,

Ty ziemska, ty objawiająca się, tyś życzliwa dla wszystkich.

Ciesząca się dziećmi i kochająca je, boska, wychowująca młodzież dziewico,

Wokół twojego tronu krąży kolistymi ruchami

Wóz zaprzęgnięty w smoki, wykrzykująca [radośnie] «elaj»,

Pojedynczo urodzona, wielodzietna bogini, wielka władczyni śmiertelnych,

Której rozliczne kształty są kwieciste, święcie kwitnące.

Przybądź, błogosławiona, godna czci, obsypująca owocami lata,

${ }^{16}$ Pantheion.pl/node- 16 .

${ }^{17}$ Łk 1, 26: „W szóstym miesiącu posłał Bóg anioła Gabriela do miasta w Galilei, zwanego Nazaret, do Dziewicy ( $\pi \rho \grave{s}_{\varsigma} \pi \alpha \rho \theta \varepsilon ́ v o v$ ) poślubionej mężowi, imieniem Józef, z rodu Dawida, a Dziewicy ( $\tau \hat{\eta} \varsigma \pi \alpha \rho \theta \varepsilon ́ v o v)$ było na imię Maryja. Anioł wszedł do Niej i rzekł: Bądź pozdrowiona ( $\chi \alpha \hat{\imath} \rho \varepsilon)$, pełna łaski, Pan z Tobą".

${ }^{18}$ Pantheion.pl/Orfeusz-Hymn-Artemidy-36. 
Sprowadzając pokój i rozkoszną zbożność

I szczęsny dostatek, wraz z królującym zdrowiem"19.

Powyższy hymn skierowany do Demeter zupełnie odbiega treścią od hymnów i modlitw kierowanych do Maryi, ale jest nieco zbliżony, gdy chodzi o ton liryczny oraz metodę literacką. Zbieżność niektórych określeń i terminów w greckiej poezji klasycznej i chrześcijańskiej nie wynika z zapożyczeń co do treści, lecz raczej z tego, że posługiwano się tym samym greckim językiem. Podobnie, gdy chodzi o formy literackie: ponieważ istniała bogata tradycja w kompozycji hymnów ku czci bogiń helleńskich, ten warsztat można było wykorzystać do tworzenia poematów ku czci Maryi. Wydaje się, że na formację muzyczną chrześcijan mogły mieć wpływ śpiewy wykonywane w teatrze. Eurypides przywrócił muzyce jej pierwotny udział z tą różnica, że przydzielił aktorom dłuższe partie śpiewane i wielkie arie solowe ${ }^{20}$. Dodajmy, że różnego rodzaju śpiewy i aklamację wykonywane były podczas uroczystości czy to religijnych czy państwowych. Wychowanie muzyczne stanowiło istotny punkt pracy w szkołach starożytnych ${ }^{21}$.

Można sobie wyobrazić, że chrześcijanie pierwszych wieków wykształceni na literaturze, w tym poezji klasycznej, byli wrażliwi na piękno stylu poezji chrześcijańskiej. Łaciński poeta Sedulius Caelius, żyjący w V w., pisał do przyjaciela Macedoniusza, że podjął się opracować Poemat Paschalny, sięgając po klasyczną metodę, ponieważ wiedział, że są tacy, którzy

„gdy, zobaczą to, co osłodzone powabem wierszy, przyjmują z takim pragnieniem serca, że częściej to powtarzając, układają i wdrażają sobie w pamięci. Myślę, że nie należy gardzić przejawem ich usposobienia [...], aby każdego jego własną zdolnością dobrowolnie pozyskać dla Boga"22.

W podobnym środowisku działali zapewne inni twórcy chrześcijańscy, w tym autor Akatystu. W tym sensie hymnografia antyczna mogła mieć wpływ na hymnografię chrześcijańską, pomimo że chrześcijanie starali się unikać poezji pogańskiej, a szczególnie utworów na cześć bogów greckich czy rzymskich.

3. Hymny chrześcijańskie. W Nowym Testamencie nie ma wprost informacji o muzyce i śpiewie, ale w tekście Nowego Testamentu są hymny (1Kor

${ }^{19}$ Pantheion.pl/Orfeusz-Hymn-Demeter-Eleuzyjskiej-40.

${ }^{20}$ Por. Kumaniecki, Historia kultury, s. 177-178: „W pieśniach chóralnych tragicy używali przede wszystkim tonacji doryckiej ze względu na jej majestatyczny charakter oraz spokrewnionej z nią tonacji miksolidyjskiej, czyli hyperdoryckiej o charakterze patetycznym".

${ }^{21}$ Por. H.-I. Marrou, Histoire de l'éducation dans l'Antiquité, t. 1: Le monde grec, Paris 1948, reprint 2000, 75: „Il reste vrai que l'ancienne éducation plaçait au premier rang, dans cette catégorie, la musique au sens étroit du mot, la musique vocale et instrumentale [...]. Agissant sur l'homme tout entier, l'enseignement du cithariste contribuait lui aussi à former les jeunes à la maîtrise de soi ( $\sigma \omega \varphi \rho о \sigma u ́ v \eta)$, à les rendre plus civilisés".

${ }^{22}$ Sedulius Caelius, Epistula ad Macedonium, w: tenże, Opera omnia. Dzieła wszystkie, thum. H. Wojtowicz, Lublin 1999, 79. 
13, 1-12; Ef 1, 1-14; Kol 1, 15-13). Jeden z nich, Magnificat, jako śpiew Maryi wyraża Jej samoświadomość: „Wtedy Maryja rzekła: Wielbi dusza moja Pana, i raduje się duch mój w Bogu, moim Zbawcy. Bo wejrzał na uniżenie Służebnicy swojej. Oto błogosławić mnie będą wszystkie pokolenia, gdyż wielkie rzeczy uczynił mi Wszechmocny" (Lk 1, 46-56). W listach św. Pawła czytamy: „Słowo Chrystusa niech w was przebywa z całym swym bogactwem: z wszelką mądrością nauczając i napominając się wzajemnie przez psalmy, hymny i pieśni duchowe, z wdzięcznością śpiewając Bogu w waszych sercach" (Kol 3, 16-17; por. Ef 5, 19). Chodzi tu o śpiewy o charakterze dziękczynnym i laudacyjnym.

Andrzej Suski, komentując powyższe wezwanie skierowane przez Apostoła Narodów do chrześcijan, umieszczone w liście do Kolosan i w liście do Efezjan, pisze:

„Samo wyrażenie oraz jego kontekst nie dają podstaw do rozróżnień znaczeniowych pomiędzy psalmem, hymnem i pieśnią, stąd wypada trzem rzeczownikom przypisać znaczenie synonimiczne. Potwierdza to również zastosowanie tychże słów w literaturze judeo-hellenistycznej, gdzie używano je zamiennie. Na uwagę zasługuje fakt, że Ef 5, 19, bardziej niż Kol 3,16, uwydatnia muzyczny aspekt hymnów, ponieważ oprócz imiesłowu adontes umieszcza także imiesłów psallontes. Prawdopodobnie hymny komponowano z myślą o śpiewie"23.

Dla naszego tematu ważne jest to, że chrześcijanie już w czasach apostolskich oddawali Bogu cześć przez śpiew i z myślą o liturgii lub innych formach modlitwy komponowali odpowiednie utwory. A. Suski dodaje, że „hymny stanowiły ważny element kultu sprawowanego we wspólnocie"24.

Do najstarszych zabytków hymnicznych młodego Kościoła należy hymn liturgiczny Didache (Nauka dwunastu Apostołów) z przełomu I i II w. Rozpoczyna się on od słów dziękczynienia Bogu Ojcu za świętą winorośl Dawida objawioną przez Jezusa ${ }^{25}$. Ten hymn jest śpiewany obecnie w kościołach, przy czym melodia jest współczesna.

O tym, że chrześcijanie śpiewali podczas zgromadzeń liturgicznych, nawet wtedy, gdy odbywali je po kryjomu, świadczy m.in. list Pliniusza Młodszego, zarządcy Pontu i Bitynii, do cesarza Trajana, w którym autor pisze, że chrześcijanie mieli zwyczaj zbierać się o świcie i śpiewać hymny na cześć Chrystusa jako Boga ${ }^{26}$. Po łacinie użyty jest tu zwrot carmen dicere, co dosłownie mogłoby znaczyć „recytować”, ale już Tertulian interpretował ten zwrot w znaczeniu

${ }^{23}$ A. Suski, Hymniczne cytaty Nowego Testamentu w świetle „, Formgeschichte”, StPł 15 (1977) 10-11. Por. H. Langkammer, Chrystologiczne hymny Nowego Testamentu. Najstarszy obraz Chrystusa, Katowice 1976.

${ }^{24}$ Suski, Hymniczne cytaty, s. 11.

${ }^{25}$ Por. Didache IX 1 - X 7.

${ }^{26}$ Por. Plinius Minor, Epistula ad Traianum. 
„śpiewać”27. A. Suski, podobnie jak inni badacze, uważa, że w liście Pliniusza łacińskie słowo carmen jest odpowiednikiem greckiego słowa ú $\mu$ vos.

Znawcy muzyki wczesnochrześcijańskiej podkreślają, że najstarsze hymny chrześcijańskie były wzorowane na śpiewach synagogalnych, a w późniejszych hymnach dostrzega się coraz bardziej wpływ hymnografii klasycznej, głównie greckiej ${ }^{28}$. W miarę upływu czasu, szczególnie na Wschodzie, rozwinęły się różne formy muzyczne (hymniczne) ${ }^{29}$. Wymienimy niektóre w sposób bardzo ogólny:

Znano formę śpiewu określaną jako troparion ${ }^{30}$; była to początkowo krótka modlitwa, zwykle jednozwrotkowa, którą śpiewano jako refren pomiędzy wersetami psalmu; wyrażała ona treść obchodzonego święta. Hymny śpiewano głównie w kościołach, gdzie przychodzili ludzie z okolicy; śpiewano je przede wszystkim podczas czuwań modlitewnych przed większymi świętami (vigiliae). Mnisi, szczególnie na pustyni, początkowo byli nastawieni niezbyt pozytywnie do hymnów, a może i do śpiewu w ogóle, później jednakże zaczęli śpiewać psalmy, a z czasem i hymny przedostawały się do klasztorów ${ }^{31}$. Później troparia śpiewano przy godzinach kanonicznych, np. Jutrzni czy Nieszporach $^{32}$. Z czasem troparia rozwinęły się w samodzielne hymny. Śpiewano je solo lub chóralnie ${ }^{33}$. Istniały też mniejsze formy hymniczne jak kathismaty i eksposteilaria; były to krótkie utwory o tematyce dnia, śpiewane z wybranymi wersetami psalmów, które nazywano stichera.

$\mathrm{Z}$ czasem popularne stały się tryptyki, czyli hymny składające się z trzech części. Układano je na cześć Chrystusa i świętych. Znany jest na przykład hymn ku czci Athenadora († 269), biskupa i męczennika ${ }^{34}$. Komponowano także tryptyki ku czci Matki Bożej.

${ }^{27}$ Por. Tertullianus, Apologeticum II 6, Documenta Catholica Omnia, 0160-0220 Tertullianus, Apologeticum, LT: „Plinius enim Secundus [...] consuluit tunc Traianum imperatorem, adlegans praeter obstinationem non sacrificandi nihil aliud se de sacramentis eorum comperisse quam coetus antelucanos ad canendum Christo ut Deo".

${ }^{28}$ Por. Wellesz, History of Byzantine Music, s. 147: „From the very beginnings of an independent Christian poetry, new hymns were modeled on patterns known from the Jewish service. Later on, when Christians came into closer touch with the surrounding pagan civilization, w new type of hymn was added, modelled on Hellenistic pagan poetry".

${ }^{29}$ Są one przedstawione w ogólnym zarysie w: Wschód Zachodowi. Greckie hymny ku czci łacińskiego biskupa Ambrożego z Mediolanu, tłum. G. Jaśkiewicz, Lublin 2012; tamże: Grzywaczewski, Wstęp, s. 9-18. Por. G. Pasini, Le fonti greche su San 'Ambrogio di Milano, SAEMO 24/1, Milano - Roma 1990, 336-431.

${ }^{30}$ Por. Troparion, w: B. Nadolski, Leksykon Liturgii, Poznań 2006, 1632.

${ }^{31}$ Por. Wellesz, History of Byzantine Music, s. 171: „Monks of the strict rule, anchorites and hermits, rejected [...] every kind of singing”. Tak było na przykład wśród mnichów na pustyniach w Egipcie.

${ }^{32}$ Por tamże, s. 174: „The Troparia had their fixed position in the Canonical Hours”.

${ }^{33}$ Por. tamże, s. 175: „Troparion need not to be performed by a single person, but it could also be sung by a choir".

${ }^{34}$ Por. Wschód Zachodowi, s. 58-56. 
Kontakiony (kontakia), kontakaria - to jakby śpiewane homilie ${ }^{35}$; są tam treści dogmatyczne, ale w mniejszym stopniu; takie śpiewy wykonywano często w ramach Jutrzni i Nieszporów. Kontakion jako rodzaj hymnu składa się z mniejszych części ib ${ }^{36}$ Kontakia miały określoną budowę: prooimion - wstęp ujmujący treść dnia (święta); nazywano tę część utworu także kukulion. Często z niego się wyłaniał refren, powtarzany wielokrotnie. Kontakion składał się z wielu, czasem do 30, zwrotek ( $i k o i$, niektórzy piszą oikoi). Kontakia należały do ważniejszych form śpiewu kościelnego na Wschodzie w okresie bizantyńskim; to określenie jest nieprecyzyjne; niektórzy umieszczają go pomiędzy dojściem do władzy cesarza Justyniana (527) a upadkiem Konstantynopola (1453). Jako bizantyńskie określa się to, co powstało w greckiej strefie językowej, po rozluźnieniu związku Wschodu z Rzymem. Włodzimierz Wołosiuk pisze, że „starożytny kontakion był szczególnie popularny na przełomie V i VI wieku" ${ }^{37}$. W klasztorach wykonywano kontakion podczas officium rannego, po odczytaniu Ewangelii.

Do wybitnych autorów różnych pieśni, w tym kontakiów, należy św. Roman Pieśniarz († 560), na Zachodzie nazywa się go Melodos. Pochodził on z Syrii, możliwe, że był pochodzenia żydowskiego ${ }^{38}$. Mówi się, że miał szczególny charyzmat do kontakiów. Hans Wilhelm Haussing powtarza pogląd innych historyków jakoby „Romanos miał napisać blisko tysiąc kontakionów”39.

Kontakiony były popularne na Wschodzie jako kunsztowne hymny składające się najczęściej z 9 części zwanych odami; każda oda wyrażała nieco inne treści. To określenie pochodzi od słowa ódós, które znaczy: droga. Wybitnym autorem kontakionów był św. Andrzej z Krety (†740). Liczne kontakiony przypisuje się św. Janowi Damasceńskiemu (675-749); znany jest też Józef z Sycylii $(† 886)$ oraz Teofan $(† 845)$ mnich z klasztoru św. Saby w Palestynie. Wiele jest różnych hymnów i pieśni, których autorzy pozostają nieznani. Czasem biskupom uzdolnionym muzycznie przypisywano autorstwo różnych hymnów, dlatego, że popierali ich śpiew w kościele oraz pozostawili je w swoich bibliotekach.

Komponowano i wykonywano także theotokiony (theotokia) - hymny ku czci Boga, a także Maryi - zawierające treści teologiczne; celem ich śpiewa-

${ }^{35}$ Por. J. Grosdidier de Matons, Recherches sur Romanos le Mélode et sur les origines de Kontakion, Paris 1961, 176: „Le kontakion est une homélie, ou, à la différence du canon qui est un poème lyrique, le texte est plus important que la musique. Le chant devrait être simple et peu orne".

${ }^{36}$ Por. H.-G. Beck, Kirche und theologische Litteratur im Byzantinishen Reich, München 1959, 263: „Hymnengeschichtlich könnte man sagen, das Kontakion bestehe aus einer Vielzahl von ungleichzeiligen Troparien. Die Strophen werden denn auch Troparien oder noch oঝkoi genannt”.

${ }^{37}$ W. Wołosiuk, Kontakion, EK IX 744.

${ }^{38}$ Por. Wellesz, History of Byzantine Music, s. 183: „The association of the name of Romanus with the rise of the Kontakion makes it possible to fix the date of its reception into Byzantine liturgy within the first decades of the sixths century. Romanus was a Jew by birth. He was born at Emesa, the Orontes, became a deacon at Berytus, and went to Constantinople in the days of Anastasius I (491-518) to join the clergy of the Theotokos church".

${ }^{39}$ H.W. Haussing, Historia kultury bizantyńskiej, tłum. T. Zabłudowski, Warszawa 1969, 236. 
nia był zarówno kult jak też propagowanie określonych treści teologicznych. Przykładem tego rodzaju kompozycji mogą być różnego rodzaju hymny układane w greckiej strefie językowej ku czci św. Ambrożego z Mediolanu; ich polskie tłumaczenie znajduje się w cytowanym powyżej opracowaniu Wschód Zachodowi ${ }^{40}$.

Stopniowo rozwijały się, szczególnie na Wschodzie, ale i na Zachodzie, śpiewy, w których diakon wypowiadał modlitwy, a lud powtarzał tę samą aklamację, na przykład Kyrie eleison. Wspomina o tym Egeria ${ }^{41}$. Tego rodza-

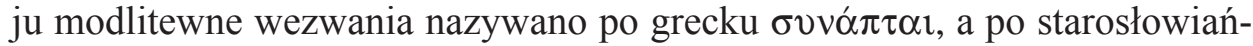
sku ektienia. Pojawiły się też litanie: wyliczanie poszczególnych tytułów czy przymiotów Chrystusa, Matki Bożej czy któregoś ze świętych. Istniały też różnego rodzaju suplikacje oraz rogationes, czyli modlitwy zanoszone w trudnych okolicznościach. Przykładem śpiewu wczesnochrześcijańskiego na Zachodzie może jest hymn Chwała na wysokości Bogu $u^{42}$, który jest śpiewany w Kościele łacińskim w święta. Hymn Ciebie Boga wychwalamy, nieznanego autora, pochodzi z okresu późniejszego ${ }^{43}$.

4. Kult Maryi w młodym chrześcijaństwie. Zapowiedź kultu Maryi widzimy w Nowym Testamencie. Anioł wita Maryję słowami: „Bądź pozdrowiona, pełna łaski, Pan z Tobą. Błogosławiona jesteś między niewiastami” (Łk $1,28)$. Mamy tu i pozdrowienie ( $\chi \alpha \hat{\imath} \rho \varepsilon)$ i stwierdzenie pełni łaski ( $\kappa \varepsilon \chi \alpha \rho \iota \tau o-$ $\mu \varepsilon ́ v \eta$ ); to zakłada wolność od grzechu, na tym stwierdzeniu opiera się wiara w niepokalane poczęcie. Jest i stwierdzenie, że Maryja jest osobą wyjątkową, inną niż wszystkie niewiasty. Maryja zaakceptowała to przesłanie. Podczas spotkania z Elżbietą powiedziała: „Błogosławioną zwać mnie będą wszystkie narody, gdyż wielkie rzeczy uczynił mi Wszechmocny” (Łk 1, 48). Tematyka maryjna pojawia się $\mathrm{w}$ najstarszych pismach chrześcijańskich, tak wschodnich, jak i zachodnich.

a) Autorzy wschodni. Św. Justyn (100-167) komentował w odniesieniu do Maryi proroctwo Izajasza: „Oto Panna pocznie i porodzi Syna” $(\mathrm{Iz} 7,14)^{44}$. Św. Ireneusz (140-202) prowadził rozważania na bazie: Adam - Chrystus;

${ }^{40}$ Zob. nota 7.

${ }^{41}$ Por. Egeria, Itinerarium seu Peregrinatio ad loca sancta 4.

${ }^{42}$ Por. N.M. Denis-Boulet, Analyse des rites et des prières de la messe, w: L'Église en prière, éd. A.G. Martimort, Paris 1961, 335: „Le Gloria fait partie d'une courte série d'hymnes très vénérables remontant à la primitive Eglise, composées à la manière des psaumes et continuant la tradition des hymnes du Nouveau Testament".

${ }^{43}$ Por. M. Wysocki, Autorstwo „Te Deum” w świetle wspótczesnych badań, „E-Patrologos” 1 (2015) z. 4, 51: „Najwcześniejsze źródła nie wspominają w ogóle, kto był autorem Te Deum”. Niektórzy przypisywali autorstwo tego hymnu św. Ambrożemu, inni Augustynowi, jeszcze inni św. Nicetasowi z Remezjany. Ponieważ w tekście hymnu da się wyróżnić kilka części, M. Wysocki stwierdza: „Nie podobna mówić o jednym autorze, ale tylko o redaktorze, który znaną już część z II wieku ewentualnie rozszerzył w IV wieku, względnie wszystkie trzy części zestawił” (tamże, s. 58).

${ }^{44}$ Por. Iustinus, Apologia 133. 
Ewa - Maryja. Stwierdził między innymi, że Dziewica Maryja rozwiązała przez swą wiarę to, co dziewica Ewa związała przez swą niewiarę ${ }^{45}$. Są to fragmenty rozważań raczej teoretycznych (teologicznych). Orygenes (185254) natomiast napisał, a zapewne i wygłosił, homilię na temat Nawiedzenia Najświętszej Panny oraz na temat hymnu Magnificat ${ }^{46}$. Homilia jest częścią liturgii, jest zatem wyrazem kultu już istniejącego.

Ogólnie mówiąc, teologowie i duszpasterze I i II w. byli dyskretni, gdy chodzi o pisanie i mówienie o Maryi oraz o oddawanie Jej publicznego kultu z obawy, by nie budzić skojarzeń z kultem bogiń pogańskich. Szczególnie niebezpieczne było rozważanie nawiedzenia Maryi przez anioła i dziewicze poczęcie (bez udziału ziemskiego ojca), gdyż to przypominało baśnie pogańskie (mitologiczne) o kontaktach cielesnych bogów helleńskich z niektórymi kobietami; z tego rodzaju związków rodzili się (rzekomo) tzw. herosi, czyli ludzie wyjątkowo zdolni, którzy dochodzili do wielkich rzeczy w polityce (jako wybitni wodzowie, królowie czy cesarze), także w dziedzinie sztuki (poeci, śpiewacy) lub w umiejętnościach tajemnych (cudotwórcy czy magowie). O tym, jak głęboko były zakorzenione takie baśnie w świadomości ludzi, świadczy historia opowiedziana przez Józefa Flawiusza ${ }^{47}$.

Jednym z najwcześniejszych i najwybitniejszych autorów pieśni i hymnów jest św. Efrem Syryjczyk (†373). Układał on pieśni ku czci Matki Bożej, na przykład: Pieśń o Najśw. Maryi Pannie (I), Pieśń o Najśw. Maryi Pannie (II), Pieśń o Ewie i Maryi, Pieśń o Maryi do Boskiego Dziecięcia, Pieśń o Maryi i o mędrcach, Pieśń o Maryi, Symeonie i Dziecięciu, Pieśń ku chwale Bożej Rodzicielki i Dziewicy Maryi, Żale Najśw. Maryi Panny nad cierpiacym Jezusem. Posiadamy je w języku polskim ${ }^{48}$.

O Matce Bożej pisali tacy autorzy, jak: Bazyli Wielki († 379), Jan Chryzostom († 407), Cyryl Aleksandryjski († 444). W jednej z jego mów tego ostatniego znajdują się wyrażenia podobne do tych, które znajdują się w Akatyście. Przytaczamy jeden fragment z mowy Cyryla:

„Witaj nam Święta, pełna tajemnic Trójco, Tyś nas wszystkich w tym kościele Bogarodzicy zgromadziła.

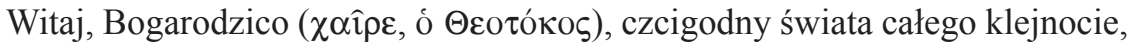
światło, co nie gaśnie, korono dziewictwa, berło prawowiernej nauki, niezniszczalna świątynio, domie Nieogarnionego, Matko Dziewico. Dzięki Tobie w Ewangelii błogosławionym się zwie Ten, który idzie w imię Pańskie (Mt 21,9).

${ }^{45}$ Por. Irenaeus, Adversus haereses 3, 22.

${ }^{46}$ Por. Origenes, Homiliae in Lucam 7, ed. H. Crouzel - F. Fornier - P. Perichon, SCh 87, Paris 1962, 154-162, thum. W. Kania: Orygenes, Homilia na Nawiedzenie Najśw. Panny, w: Ojcowie Kościota greccy i syryjscy. Teksty o Matce Bożej, Niepokalanów 1981, 26-29; tamże 8, SCh 87, 164-172, thum. W. Kania: Orygenes, Homilia na temat hymnu Magnificat, w: Ojcowie Kościoła greccy i syryjscy, 30-32.

${ }^{47}$ Por. Iosephus Flavius, Antiquitates Iudaicae XVIII 3, 3-4.

${ }^{48}$ Por. Ojcowie Kościoła greccy i syryjscy, s. 33-75. 
Witaj, Tyś Nieskończonego w swym łonie dziewiczym nosiła.

Dzięki Tobie czczona jest Trójca,

Dzięki Tobie w całym świecie hołd odbiera Krzyż drogocenny,

Dzięki Tobie cieszy się niebo, radują się aniołowie i archaniołowie, uciekają demony.

Dzięki Tobie cały świat pogrążony w służbie bałwanom poznaje prawdę, wierni otrzymują chrzest i olej wesela ${ }^{49}$.

Dzięki Tobie na całym okręgu ziemskim powstają kościoły i narody wchodzą na drogę pokuty.

Dzięki Tobie Jednorodzony Syn Boży zajaśniał jako światło wśród tych, co siedzieli w ciemnościach i w cieniu śmierci.

Dzięki Tobie prorocy prorokowali, a apostołowie głosili Dobrą Nowinę.

Dzięki Tobie umarli zmartwychwstają, a rządzący sprawują władzę" 50 .

Pozdrowienie ,witaj” ( $\chi \alpha \hat{\imath} \rho \varepsilon)$, które tutaj występuje, wielokrotnie powtarza się w Akatyście. Cyryl, zanim zacznie mówić o Maryi, zwraca się do Trójcy Świętej. Autor Akatystu na początku zwraca się do Chrystusa mówiąc:

„Kiedy (archanioł) ujrzał, że na jego bezcielesny głos, bierzesz na siebie ciało, Panie (Kúpı), stanął w zachwycie"s1.

Cyryl wypowiada wiele laudacji pod adresem Maryi mając świadomość, że znajduje się wobec Trójcy Świętej. Autor Akatystu, wypowiada wiele laudacji pod adresem Maryi, mając świadomość, że znajduje się w obecności Chrystusa. W jednej z inwokacji Cyryla, skierowanej do Maryi, mianowicie: „Dzięki Tobie czczona jest Trójca" można dostrzec podobieństwo do jednej z inwo-

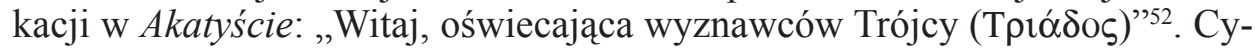
ryl Aleksandryjski przedstawia Maryję jako Tę, która sprawia radość aniołom, a demony przyprawia o szok i rozpędza je. Podobna myśl znajduje się w Akatyście: „Witaj, cudzie, o którym brak jest słów aniołom. Witaj, rano

${ }^{49}$ W Kościele wschodnim po chrzcie (odpuszczenie grzechów i włączenie do Kościoła) następuje namaszczenie olejem (dar Ducha Świętego). Potem nie ma bierzmowania jako oddzielnego sakramentu.

${ }^{50}$ Cyrillus Alexandrinus, Homilia IV. De Maria deipara in Nestorium, PG 77, 992-996, thum. W. Kania: Cyryl Aleksandryjski, Mowa soborowa ku czci Bogarodzicy, w: Ojcowie Kościoła greccy i syryjscy, s. 101. W dalszej części tej Mowy Cyryl napiętnował Nestoriusza, który - jak wiadomo - odrzucał tytuł Bogurodzica (Theotokos). Mówił między innymi: „Któż ci radził głosić tę zgubną naukę? Któż ci pomagał szerzyć tę nieszczęsną chorobę? [...]. W nadziei zdobycia władzy nad wszystkimi kościołami zapomniałeś o Tym, który cię z gnoju wywiódł do niebiańskiej godności. Patrząc na stworzenie straciłeś z oczu Stwórcę. Bałamuciłeś świat zwodniczymi mowami, bluźniłeś świątyni Bożej, dzieliłeś Tego, który się narodził z Maryi, siałeś błędy i szaleństwo, które trudno będzie wykorzenić" (tamże, s. 103). Było to za panowania cesarza Teodozjusza I.

${ }^{51}$ Akatyst ku czci Bogurodzicy, oikos I (strofa wstępna), thum. www.cyrylimetody.marianie.pl/ akatystbt.html (dostęp 10.02.2018).

${ }^{52}$ Tamże, oikos (strofa) IX, chairesmos (pozdrowienie) 4. 
zadana demonom" ${ }^{53}$. Po grecku jest to nawet powiedziane do rymu: „X $\alpha \hat{\imath} \rho \varepsilon$,

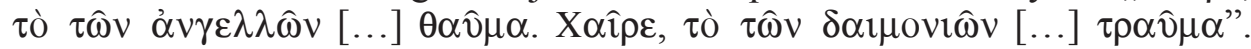
W dalszej części hymnu jest powiedziane: „Witaj, która piekło ogołacasz” ${ }^{54}$. Cyryl podkreśla, że „świat pogrążony w służbie bałwanom poznaje prawdę” dzięki Maryi. Autor Akatystu śpiewa: „Witaj, ujawniająca ułudę bałwanów $(\tau \hat{\omega} \nu \operatorname{\varepsilon i\delta } \omega \dot{\lambda} \hat{\omega} \nu)^{\prime \prime}{ }^{5}$.

O Matce Bożej pisali także inni autorzy jak Proklos z Konstantynopola $(†$ 446), German z Konstantynopola († 737), Jan Damasceński († 749). Wiele pisali o Matce Bożej autorzy późniejsi. Liczne są w tekście Akatystu referencje do autorów wczesnochrześcijańskich ${ }^{56}$.

b) Autorzy zachodni ${ }^{57}$. Obszerny komentarz do słów Izajasza „Oto Panna pocznie i porodzi Syna” (Iz 7, 14) znajdujemy u Tertuliana $(\dagger 220)$. Pisze on między innymi:

„Panna poczęła i porodziła Emanuela, to jest Boga z nami. Na tym polegają nowe narodziny, że człowiek rodzi się w Bogu, odkąd Bóg narodził się człowieku, przyjąwszy ciało ze starego nasienia bez tego nasienia"

Hipolit Rzymski († 235) nazywał Maryję Matką Człowieka i Boga i podkreślał, że Chrystus narodził się z Ducha Swiętego i Maryi ${ }^{59}$.

O Maryi pisali inni autorzy jak: św. Hilary z Poitiers († 367), św. Ambroży $(† 397)$, św. Zenon z Werony $(† 375)$, św. Hieronim († 419), św. Maksym $z$ Turynu († 423), św. Augustyn († 430), Jan Kasjan († 435), św. Piotr Chryzolog z Rawenny († 450), św. Leon Wielki († 460), św. Fulgencjusz (†533), św. Grzegorz Wielki († 604), św. Ildefons z Toledo († 667). Podobnie, jak na Wschodzie, pisali o Maryi liczni autorzy późniejsi. Trudno by się dopatrzeć wpływów łacińskich w tekście Akatystu, a ewentualne podobieństwa moga pochodzić z faktu wyznawania tej samej wiary chrześcijańskiej na Wschodzie i Zachodzie, w tym z akceptacji tej samej nauki o Matce Bożej.

Przełomowe znaczenie miała uchwała Soboru w Efezie (431) zwołanego za zgodą papieża Celestyna; na pierwszej sesji soborowej w dniu 22 czerwca 431 roku odczytano drugi list Cyryla biskupa Aleksandrii do Nestoriusza biskupa Konstantynopola ${ }^{60}$. Dotyczył on przede wszystkim natury Chrystusa. Czytamy tam między innymi:

${ }^{53}$ Tamże, oikos III, chairesmoi 7 i 8.

${ }^{54}$ Tamże, oikos VI, chairesmos 11.

${ }^{55}$ Tamże, oikos XI, chairesmos 4.

${ }^{56}$ Por. Toniolo, Akathistos, s. 145-344.

${ }^{57}$ Wybór tekstów maryjnych autorów łacińskich posiadamy w języku polskim: Ojcowie Kościoła łacińscy. Teksty o Matce Bożej, tłum. W. Eborowicz - W. Kania, Niepokalanów 1981.

${ }^{58}$ Tertullianus, De carne Christi 17, 2-3, ed. J.-P. Mahé, SCh 216, Paris 1975, 280, thum. W. Eborowicz: Tertulian, O ciele Chrystusa 17, w: Ojcowie Kościoła łacińscy, s. 21.

${ }^{59}$ Por. Hippolytus, Benedictiones Isaac et Iacob.

${ }^{60}$ Por. M. Starowieyski, Sobory Kościoła niepodzielonego, Tarnów 1994, 65: „Odczytano wyznanie wiary «Soboru 318 Ojców» (to znaczy nicejskie), następnie drugi list Cyryla do Nestoriusza 
„Słowo Boże przyjęło ludzkie ciało i stało się człowiekiem. Nie mówimy, że

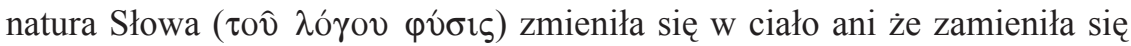
w pełnego człowieka, złożonego z ciała i duszy, lecz twierdzimy raczej, że Słowo jednocząc się przez unię hipostatyczną ( $\kappa \alpha \theta^{\prime}$ í $\pi$ ó $\left.\sigma \tau \alpha \sigma \iota v\right)$ z ciałem ożywionym rozumną duszą, stało się człowiekiem w sposób nie do wypowiedzenia i nie do pojęcia i że zostało nazwane Synem Człowieczym (viòs

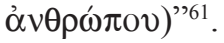

Dla naszego tematu ważne jest to, że sobór przyznał Maryi tytuł Bogurodzica

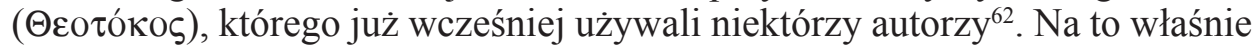
powoływał się Cyryl z swoim liście do Nestoriusza:

„Tak samo myśleli święci Ojcowie. Przeto nie wahali się nazwać świętej

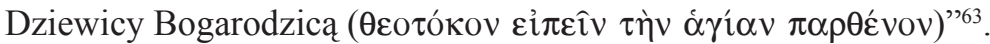

Tenże tytuł znajduje się również w trzecim liście Cyryla do Nestoriusza, który także odczytano na soborze. Czytamy w nim:

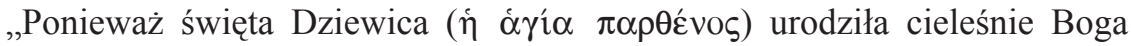
zjednoczonego hipostatycznie z ciałem, mówimy, że jest ona Bogarodzicą

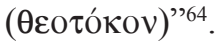

Dodajmy, że Cyryl Aleksandryjski pozostawał w kontakcie z papieżem Celestynem, gdy chodzi o zwalczanie poglądów Nestoriusza.

Historyk Sokrates Scholastyk nie wchodzi w szczegóły doktrynalne, lecz opisuje burzliwy przebieg obrad soboru w Efezie ${ }^{65}$. Teologowie na ogół są zgodni co do znaczenia tego soboru dla teologii w ogóle oraz dla mariologii ${ }^{66}$. Przyczynił się on do odrzucenia teorii nestoriańskich, a także sprawił, że kult Maryi zaczął się rozwijać w sposób bardziej dynamiczny niż poprzednio, co uwidoczniło się w liturgii, tak na Wschodzie ${ }^{67}$, jak i na Zachodzie ${ }^{68}$. Kallistos Ware, teolog prawosławny, pisze, że ,znaczenie słowa Theotokos jest tak samo

i po głosowaniu, czy jest on zgodny z wyznaniem wiary, został przez sobór przyjęty. Trzeci list Cyryla i jego anatematyzmy wprawdzie odczytano, ale nie głosowano nad nimi”.

${ }^{61}$ Cyrillus Alexandrinus, Epistula ad Nestorium 2, 3, DSP 1, Kraków 2001, 113.

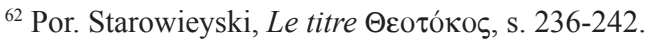

${ }^{63}$ Cyrillus Alexandrinus, Epistula ad Nestorium 2, 6, DSP 1, s. 117-119.

${ }^{64}$ Tenże, Epistula ad Nestorium 3, 26, DSP 1, s. 151.

${ }^{65}$ Por. Socrates Scholasticus, HE VII 34. Zob. A. d'Alès, Dogme d'Ephèse, Paris 1931, 116-156.

${ }^{66}$ Por. Maryja w tajemnicy Chrystusa, red. C. Napiórkowski-S. Longosz, Niepokalanów 1997.

${ }^{67}$ Por. Denis-Boulet, Analyse des rites, s. 395: „Les liturgies orientales ont introduit dans l'anaphore la mémoire de la Vierge après le Concile d'Ephèse. C'est d'ailleurs la seule mention de Marie que fît la messe antique. Gloriosae, semper virginis, Genetricis Dei - les trois titres sont les mêmes qu'aux diptyques égyptiennes du VI ${ }^{\mathrm{e}}$ siècle".

${ }^{68}$ Por. Dom B. Capelle, Les fêtes mariales, w: L'Église en prière, s. 747: „Un culte théologique de la Vierge Marie apparaît déjà dans le Communicantes de la messe [...]. Le titre Genetrix Dei que l'on y donne à la Vierge est à remarquer [...]. Or l'insertion du Communicantes dans le canon de la messe est antérieure au pontificat de S. Léon (440-461)". 
ważne dla doktryny o Wcieleniu jak słowo homoousios w nauce o Trójcy"69. Część chrześcijan w Syrii i Mezopotamii nie przyjęła uchwał tego soboru ${ }^{70}$, jednakże w Kościołach wschodnich, szczególnie w Syrii, kult Maryi istniał już wcześniej i rozwijał się nadal. Jerzy Woźniak podkreśla, że „większość monofizytów (w Syrii) poparła stanowisko Soboru Efeskiego i wystapili oni w obronie Theotokos" "71. Na Wschodzie, szczególnie w tradycji judeo-chrześcijańskiej, czczono Maryję jako typ i obraz Kościoła ${ }^{72}$.

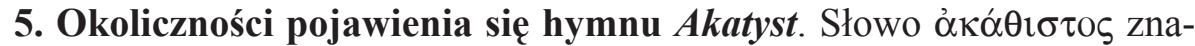
czy „nie siedzący”, czyli jest to hymn, który należało śpiewać w postawie stojącej. Jest to postawa zasadnicza w Kościele wschodnim. W postawie stojącej należało zanosić modlitwy przede wszystkim w niedzielę i w uroczyste święta. Od strony muzycznej jest to dzieło bizantyńskie wyjątkowej wartości. Wydaje się, że melodia, jaką znamy obecnie, nadająca się do wykonania wielogłosowego, jest późniejsza, bowiem śpiewy greckie, szczególnie kościelne, były zasadniczo jednogłosowe.

Główną treścią Akatystu jest tajemnica Wcielenia. Pierwsza część ma charakter bardziej narratywny, a druga bardziej spekulatywny i liryczny. Liczne wezwania modlitewne ( $\chi \alpha \iota p \varepsilon \sigma \mu o i ́)$ skierowane do Maryi ukazują ścisły związek mariologii z chrystologia ${ }^{73}$. Według najstarszych źródeł wykonano go po raz pierwszy w Konstantynopolu w kościele Blakheranai w nocy 7 sierpnia 626 r. w czasie nocnego czuwania o charakterze dziękczynnym za odparcie ataku wrogów (Persów) na miasto stołeczne ${ }^{74}$. Było to za cesarza Herakliusza i patriarchy był Sergiusza ${ }^{75}$.

${ }^{69} \mathrm{~K}$. Ware, L'orthodoxie. L'Église des sept Conciles, transl. F. Lhoest, Paris 2002, 36.

${ }^{70}$ Por. Dom B. Botte, Rites et familles liturgiques, w: L'Église en prière, s. 22: „Les Syriens orientaux n'acceptèrent pas les décisions d'Ephèse et devinrent nestoriens".

${ }^{71}$ J. Woźniak, Recepcja „, Theotokos” u Ojców syryjskich, w: Maryja w tajemnicy Chrystusa, s. 75.

${ }^{72}$ Por. E. Testa, The faith of the Mother Church, transl. P. Rotondi, Jerusalem 1992, 80: „The Judeo-Christian doctrine which has identified Mary with the Church is well known. It is found in Mark the Deacon's semiotic square. It is repeated in the Discourse of St. Barsabbas on Christ and the Churches (par. 21). [...]. From the Judeo-Christianity the teaching spread into Syria, so that Ephrem could say that we call the Church by Mary's name. It passed then into Egypt [...] and it seems that the teaching from there went to Ephesus [...]. Under many viewpoints Mary appears as the ideal figure of the Church".

${ }^{73}$ Por. Th. Nikolaou, Akathistos Hymnos, w: Marienlexikon, opr. R. Bäumer - L. Scheffczyk, Regensburg 1988, 66: „Die vielen mariologischen Aussagen in diesem Teil bilden ein ausgezeichnetes Beispiel für die einige Verbindung der Mariologie mit der Christologie in der orthodoxen Kirche".

${ }^{74}$ Armia agresorów liczyła ponad 100 tys. żołnierzy; wiadomo, że samych Awarów było około 80 tys. Grecy mieli tylko 12 tys. żołnierzy w tym czasie i na tym terenie. Dowodził nimi generał Bonus. W tym czasie cesarz Herakliusz z główną armią był w Mezopotamii; tam pokonał dwa odziały wojsk perskich. Na skutek tego dowódca perski wycofał swą armię spod Konstantynopola bez walki. Ludzie mieli powód do radości i zdumienia. Liczne źródła podają, że patriarcha Sergiusz wezwał ludność do modlitwy, podają też, że panowało powszechne przekonanie, iż to zdumiewające ocalenie Konstantynopola było skutkiem modlitwy.

${ }^{75}$ Por. C. Morrisson, La continuité de l'Empire Romain en Orient, w: Le monde byzantin, éd. 


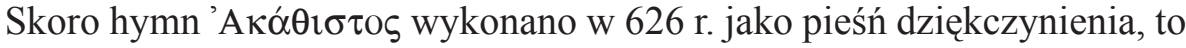
znaczy, że był on skomponowany wcześniej i znany śpiewakom. Tuż po zwycięstwie nie było czasu na tak kunsztowną kompozycję, ani na to, by się przygotować do jej odśpiewania. Posłużono się hymnem już istniejącym, dodając tylko inwokację: waleczna hetmanko ( $\tau \hat{\eta} \dot{v} \pi \varepsilon \rho \mu \alpha ́ \alpha \omega \sigma \tau \rho \alpha \tau \eta \gamma \hat{\omega})^{76}$. Treść nie wskazuje, by powodem do kompozycji hymnu było zwycięstwo militarne. Ludzie zebrani na modlitwie (lub tylko chórzyści) zaśpiewali hymn 'Aкó $\theta \imath \sigma \tau o \varsigma$ jako dziękczynienie Matce Bożej za odparcie wrogów dlatego, że był to najpiękniejszy hymn ku Jej czci, jaki znali.

Wydaje się, że mógł być on skomponowany z myślą o uroczystości Zwiastowania Najświętszej Maryi Pannie, którą obchodzono 25 marca albo z myślą o Bożym Narodzeniu, które na Wschodzie obchodzi się do dziś łącznie w uroczystością Objawienia Pańskiego (Trzech Króli) w dniu 6 stycznia. Niektórzy przypuszczają, że hymn 'Aкó $\theta i \sigma \tau o \varsigma$ mógł został skomponowany w latach 530-533, wtedy bowiem cesarz Justynian zatwierdził uroczystość Zwiastowania Najświętszej Maryi Pannie; to oznaczało uznanie tego dnia za święto państwowe.

Z późniejszej historii wiemy, że Akatyst wszedł w użycie w Kościele greckim jako modlitwa dziękczynna po zwycięskiej walce, a takich walk było dość dużo, gdyż cesarstwo wschodnie było atakowane przez różne pomniejsze narody, tak od strony wschodniej, jak i zachodniej (w tym przez Słowian), potem przez muzułmanów, ale na ogół wychodziło z tych walk zwycięsko, gdyż jego ogólna sytuacja w tym czasie, tak pod względem gospodarczym, jak i militarnym, była dość dobra. To znaczy, że przez pewien czas (dość długi) Akatyst pełnił taką funkcję na Wschodzie, jak hymn Te Deum laudamus (Ciebie Boga wyławiamy) w Kościele łacińskim. Potem zaczęto go śpiewać w Wielkim Poście, podobnie jak w Polsce Gorzkie Żale.

6. Autorstwo, wydania oryginału, thumaczenia. Kwestia autorstwa Akatystu wydaje się trudna, a zdania badających to zagadnienie są podzielone. W ciagu wieków nie było pewności w tej sprawie. A. Bober napisał: „Mistrzem kontakionów był Romanos, a klasycznym jego kontakionem jest jego $\mathrm{Aka}$ thistos. Ostatnio wydawca krytycznego tekstu Akathistosa G. Meersserman wypowiada tylko powszechnie uznaną opinię, kiedy pisze, że Akathistos jest najpiękniejszym, najgłębszym i najstarszym hymnem całej chrześcijańskiej

C. Morrison, t. 1: L'Empire d'Orient, Paris 2004, 44: „En 626 Héraclius lui-même est pris à revers [...]. Les renforts envoyés par Héraclius arrivent en août et la flotte byzantine brûle les monoxyles slaves qui devaient transporter les troupes perses de Chalcédoine sur la rive européenne. Le patriarche Serge mobilise les énergies en menant l'icône de la Vierge des Blachernes en procession sur les remparts, refuse de rendre la ville et le siège est levé en août, libération miraculeuse célébrée dans le proèmion de l'hymne Acathiste en l'honneur de la Vierge, un kontakion plus ancien remanié à cette occasion".

${ }^{76}$ Por. Nikolaou, Akathistos Hymnos, s. 66: „Das ursprüngliche Prooemion ( $\tau \hat{\eta}$ vं $\varepsilon \rho \mu \alpha ́ \alpha \omega$ $\sigma \tau \rho \alpha \tau \eta \gamma(\hat{\omega})$ auf die Ereignisse im Jahre 626 angeht". 
literatury"77. A. Bober ma na myśli hymny w sensie ścisłym, a nie pieśni ku czci Matki Bożej, bo takie komponowano i śpiewano wcześniej. Gdy chodzi o autorstwo hymnu, to zdaje się, że pogląd A. Bobera jest trochę uproszczony, gdyż zdanie znawców tego zagadnienia nie jest tak jednoznaczne.

Niektórzy przypisywali autorstwo Akatystu św. Germanowi, biskupowi Konstantynopola. Tak podaje Gilles Gerard Meerseman, wydawca tekstu greckiego i łacińskiego. Utwór poprzedzony jest wprowadzeniem: Hymnus Sancte Dei Genetricis Marie victoriferus atque salutatorius a sancto Germano Constantinopolitano rithmice compositus, per singulas alphabeti litteras inchoans singulos versus ${ }^{78}$. Meerseman nie podziela tego poglądu i zaznacza, że German wprowadził śpiew tegoż hymnu do liturgii na Wschodzie ${ }^{79}$.

Polski specjalista w dziedzinie hymnografii greckiej P.F. Krypiakiewicz uważał, że autorem Akatystu jest Roman Pieśniarz ${ }^{80}$. Egon Wellesz nie był pewien autorstwa hymnu, ale przychylał się ku opinii, że jest to dzieło Romana Pieśniarza ${ }^{81}$. Paul Maas i Constantine A. Trypanis także przyjmują lub raczej dopuszczają autorstwo Romana Pieśniarza (Melodosa) jako możliwe ${ }^{82}$, a Jean Grosdidier de Matons zgłosił co do tego wattpliwości ${ }^{83}$. Wiadomo, że Roman Pieśniarz jest autorem wieku pieśni i hymnów kościelnych; znana jest jego pieśń Maryja pod krzyżem ${ }^{84}$. Badacze zauważają podobieństwa pomiędzy hymnami Romana Pieśniarza a Akatystem, ale wielu uważa, że nie

${ }^{77}$ AP, s. 512.

${ }^{78}$ Tekst grecki i łaciński Akatystu, w: Meersseman, Der Hymnos Akathistos, t. 1, s. 100-127. Dostrzegamy tu późno-łacińską pisownię: Sancte Marie zamiast Sanctae Mariae.

${ }^{79}$ Por. tamże, s. 39: „Vom Kompilator selbst wurde die Behauptung a sancto Germano patriarcha compositus in die ursprügnliche Überschrift interpoliert, um den ganzen Hymnus dem hl. Germanus zuzuchreiben, obwohl der 3. Paragraph des Vorberichtes den Patriarchen nicht als Dichter des Liedes bezeichnet, sondern nur als Urheber der jährlichen Feier der Befreiung Konstantinopels durch das Absingen des Hymnus in der Blachernen Kirche und in allen Kirchen Griechenlands am Feste der Verkündigung Mariens".

${ }^{80}$ Por. Peltomaa, The Image of the Virgin Mary, s. 45: „P.F. Krypiakiewicz, whose article De Hymni Acathisti Auctore from the year 1909 has strongly influenced ideas about the theological content of the Akathistos [...]. He believed that Romanos had composed the Akathistos whilst still in Syria".

${ }^{81}$ Por. Wellesz, A History of Byzantine Music, s. 191: „The uncertainty of authorship is particularly embarrassing in the case of the most famous hymn of the Byzantine Church, the Akathistos". Ibidem, s. 196: „Although, as work progressed, the scales turned more and more, in favour of Romanos' authorship of the Akathistos".

${ }^{82}$ Por. Peltomaa, The Image of the Virgin Mary, s. 42: „But Maas supported the authorship of Romanos as did Trypanis".

${ }^{83}$ Por. J. Grosdidier de Matons, Romanos le Melode et les origines de la poésie de Byzance, Paris 1977, 36: „The dogmatic teaching on the on the Incarnation in Romanos does not have sufficient originality to enable us to detect his hand in the Akathistos". Jest to cytat w thumaczeniu Peltomaa, The Image of the Virgin Mary, s. 45.

${ }^{84}$ Por. Romanus Melodus, Hymnus 35, ed. J. Grosdidier de Matons, SCh 128, Paris 1967, 160-186, thum. W. Kania: Św. Roman Piewca, Maryja pod Krzyżem, w: Ojcowie Kościoła greccy i syryjscy, s. 110-116. 
są one wystarczające, aby przypisać mu autorstwo jako pewne. Agnostyczne stanowisko w tej kwestii przyjmują wydawcy The Oxford Dictionnary of the Christian Church $^{85}$. Niemieccy autorzy podręcznika do patrologii pisali w roku 1978: „Za autora (Akatystu) uważa się Grzegorza Pisidesa, obydwóch patriarchów Konstantynopola, Sergiusza i Germana, zwłaszcza zaś Romana (Melodosa)" "86. Piszący po niemiecku badacz Theodor Nikolaou powstrzymuje się od opinii na temat autorstwa Akatystu ${ }^{87}$. Jeannine Vereecken uważa, że spośród osób wymienianych jako autorzy Akatystu najbardziej na uwage zasługuje Roman Pieśniarz ${ }^{88}$.

Leena Mari Peltomaa, przytoczywszy opinie kilku teologów na ten temat, stwierdza, że nie ma argumentów za przyjęciem Romana Pieśniarza jako autora $A$ katystu ${ }^{89}$, ale nie podaje racji, aby taką możliwość wykluczyć. Ermanno M. Toniolo, w swej monografii, wydanej w 2017 r., przychyla się do opinii o autorstwie Romana Pieśniarza ${ }^{90}$, jednakże jest świadomy, że wielu badaczy nie zgadza się z taką opinią.

Tekst Akatystu zachował się w całości na manuskryptach od X do XVI w. Editio princeps opracował Aldus Manutius, Poetae christiani veteres, Venice 1501 . Już na przełomie VIII i IX w. 'A אó $\theta \imath \sigma \tau o \varsigma$ został przetłumaczony na język łaciński; najpierw prawdopodobnie w Wenecji ${ }^{11}$, a potem pojawiły się także inne tłumaczenia. Wersja łacińska i grecka znajduje się w PG 92, 1335-1398. Znane jest wydanie: E. Wellesz, The Akathistos. Monumenta Musicae Byzantinae, Transcripta IX, Copenhagen 1957. Wydania krytycznego tekstu według współczesnych zasad dokonał C.A. Trypannis: Fourteen Early Byzantine Cantica, Vienna 1968, 17-39. Grecka wersja Akatystu w opracowaniu metrycznym znajduje się w dziele E.M. Toniolo, Akathistos. Inno alla Madre di Dio. Edizione metrica, Mistagogica, Commento al testo, Roma 2017, 54-77.

${ }^{85}$ Por. Acathistus, w: The Oxford Dictionnary of the Christian Church, s. 9: „It may be the work of St. Romanos Melodus, although this attribution is disputed".

${ }^{86}$ Altaner, s. 881.

${ }^{87}$ Por. Nikolaou, Akathistos Hymnos, s. 66: „Der Autor und die Zeit der Absaffung des Akathistos sint unbekannt".

${ }^{88}$ Por. Vereecken, L'hymne Acathiste, s. 360: „Parmi ces noms seul celui de Romanos entre en ligne de compte".

${ }^{89}$ Por. Peltomaa, The Image of the Virgin Mary, s. 48: „All in all, leaving aside the separate question of the form of the kontakion, it becomes clear that there are no facts to support the authorship of Romanos".

${ }^{90}$ Por. Toniolo, Akathistos, s. 80: „Ma poiché anche di recente viene riproposto da alcuni come autore probabile o addirittura come autore cert il celebre innografo greco del secolo VI, Romano il Melode".

${ }^{91}$ Por. Meersseman, Der Hymn Akathistos, s. 50: „Weil wir die Entstehung der lateinischen Akathistos-Akoloutie in Vendig zwischen 787 und 813 ansetzen konnten, so ergibt sich von selbst, dass eben Bishop Christophorus I als Verfasser in Betracht kommt”. Inne tłumaczenie miał wykonać opat Hilduin w Saint Denys we Francji ok. 832 roku. Podobno było tam wielu mnichów pochodzenia greckiego (tamże, s. 51). 
Obecnie liczne są przekłady tego hymnu na języki współczesne. Najbardziej dostępne, a może i znane w Polsce, jest tłumaczenie opublikowane w Internecie przez Mariański Dom Studiów Świętych Cyryla i Metodego (www. cyrylimetody.marianie.pl/akatystbt.htm; autor nie jest podany). Na tejże stronie jest najstarsze polskie thumaczenie wykonane przez ks. Tymoteusza Szczurowskiego OSBM, przełożonego klasztoru w Białej Podlaskiej, umieszczone w książce Misja Bialska Całoroczna, Supraśl 1792, 164-184. Ks. Roman Piętka MIC, proboszcz w Kostomłotach k. Terespola dokonał digitalizacji tego teksu (25.03.2009), zachowując jego staropolską formę. Inne tłumaczenia Akatystu znajdują się w następujących wydaniach: A. Bober, Antologia patrystyczna, 516-530; Ojcowie Kościoła greccy i tacińscy. Teksty o Matce Bożej, Niepokalanów 1981, 265-282; M. Bednarz, Akatyst ku czci Bogurodzicy. Starożytny hymn Maryjny z dodatkiem oficjów towarzyszacych, red. J.S. Gajek - R. Piętka, Rzym 1980; Akatyst ku czci Bogurodzicy, red. W. Klinger, Opole 2017.

$* * *$

Zarysowaliśmy, w sposób ogólny, kontekst, w jakim powstał słynny hymn

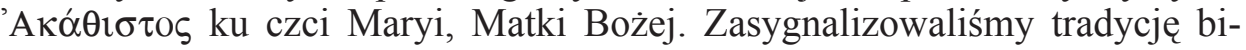
blijną Starego i Nowego Testamentu, hymnografię helleńską, hymnografię wczesnochrześcijańską oraz pisma patrystyczne na temat Maryi. Powyższe opracowanie może posłużyć jako wprowadzenie do pracy nad treścią Akatystu, czyli nad jego teologią, znaczeniem dla kultu Maryi oraz dla duchowości chrześcijańskiej.

\section{THE CIRCUMSTANCES OF THE COMPOSITION OF THE HYMN AKATHISTOS IN HONOUR OF THE BLESSED VIRGIN MARY}

(Summary)

The author of this article tries to situate the famous Greek Hymn Akathistos in its large context. He presents the Old Testament tradition, especially the Psalms, and the New Testament tradition: Christological hymns and the person of Mary in the Gospel. The Christians of the first centuries used to sing hymns during their meetings of prayer. The old Hellenic tradition in poetry and music could also have influence on the Christian poetry and music, especially on the formal aspect of such compositions. It seems to be obvious that the Akathistos was inspired by the theological considerations on Mary as Christ's Mother. This hymn is a great praise of Mary as Theotokos; this title was accepted officially in the Church by the Council of Ephesus (431). The exact date of the composition of the hymn is not known; it is only known that this hymn was sung in 626 in Constantinople as thanksgiving to Mary for the expelling of the aggressors (a regiment of the Persian army). The question of 
authorship of Akathistos is still discussed; most scholars attribute it to Romanos Melodus, but such an opinion is considered as probable. The aim of this article is to introduce the lector into the study on the theology of the Akathistos (Christology and Mariology). Surely, such a study can be precious for the Christian spirituality.

Key words: Mary, God's Mother, hymn, Akathistos, Theotokos.

Słowa kluczowe: Maryja, Bogurodzica (Bogarodzica), hymn, Akatyst, Theotokos.

\title{
BIBLIOGRAFIA
}

\author{
Źródła \\ Akatyst - tekst oryginalny [układ chronologiczny]
}

Der Hymn Akathistos im Abendland, ed. G.G. Meersseman, Freiburg 1958, 100-127 [tekst grecki i łaciński, wyd. krytyczne].

Fourteen Early Byzantine Cantica, ed. C.A. Trypanis, Wiener Byzantinische Studien 5, Wien 1968, 17-39 [tekst grecki i angielski, wyd. krytyczne].

Akathistos. Inno alla Madre di Dio. Edizione metrica. Mistagogia, Commento al testo, E. Toniolo, Roma 2017, 54-77 [tekst grecki, układ metryczny, wyd. krytyczne].

Akatyst - polskie thumaczenia [układ chronologiczny]

Akatyst ku czi Bogurodzicy, w: www.cyrylimetody.marianie.pl/akatystbt.htm; autor thum. nie jest podany.

Akatyst, thum. T. Szczurowski (OSBM), w: Misja Bialska Całoroczna, wyd. Supraśl 1792, 164-184 [w internecie na w/w stronie znajduje się wersja elektroniczna tego thum. w opr. R. Piętki (25.03.2009)].

Hymnos Atkathistos, tłum. A. Bober, w: Antologia patrystyczna, Kraków 1965, 516-530.

Hymn Akathistos, thum. W. Kania, w: Ojcowie Kościoła greccy i łacińscy. Teksty o Matce Bożej, Niepokalanów 1981, 265-282.

Akatyst ku czci Bogurodzicy. Starożytny hymn Maryjny z dodatkiem oficjów towarzyszqcych, thum. M. Bednarz, red. J.S. Gajek - R. Piętka, Rzym 1980.

Akatyst ku czci Bogurodzicy, red. W. Klinger, Opole 2017.

\section{Pisma patrystyczne}

Cyrillus AleXAndrinus, Epistula ad Nestorium 2, tekst grecko-łacińsko-polski, układ i oprac. A. Baron - H. Pietras, tłum. A. Baron - H. Pietras - T. Wnetrzak, ŹMT $24=$ DSP 1, Kraków 2001, 108-119.

Cyrillus Alexandrinus, Epistula ad Nestorium 3, tekst grecko-łacińsko-polski, układ i oprac. A. Baron - H. Pietras, tłum. A. Baron - H. Pietras - T. Wnetrzak, ŹMT $24=$ DSP 1, Kraków 2001, 132-157.

Cyrillus Alexandrinus, Homilia IV. De Maria deipara in Nestorium, PG 77, 992-996, tłum. W. Kania: Cyryl Aleksandryjski, Mowa soborowa ku czci Bogarodzicy, w: Ojcowie Kościoła greccy i syryjscy. Teksty o Matce Bożej, opr. W. Kania, Niepokalanów 1981, 101-104. 
Didache, ed. W. Rordorf - A. Tuilier, SCh 248, Paris 1978, thum. A. Świderkówna: Didache (Nauka dwunastu Apostołów), w: Pierwsi Świadkowie, red. M. Starowieyski, OŻ 8, Kraków, 1998², 39-52.

Egeria, Itinerarium seu Peregrinatio ad loca sancta, ed. P. Maraval, SCh 296, Paris 1982.

Ephraem Syrus, Carmina Sõgyâta 2, CSCO 186, 199-203, thum. W. Kania: Efrem Syryjczyk, Pieśń Maryi do Boskiego Dziecięcia, w: Ojcowie Kościoła greccy i syryjscy. Teksty o Matce Bożej, Niepokalanów 1981, 44-48.

Ephraem Syrus, Carmina Sõgyâta 3, CSCO 186, 203-209, thum. W. Kania: Efrem Syryjczyk, Pieśń o Maryi, Symeonie i Dziecięciu, w: Ojcowie Kościoła greccy i syryjscy. Teksty o Matce Bożej, Niepokalanów 1981, 60-68.

Ephraem Syrus, Hymni de Ecclesia 35, CSCO 198, 87-90, tłum. W. Kania: Efrem Syryjczyk, Pieśn o Ewie i Maryi, w: Ojcowie Kościoła greccy i syryjscy. Teksty o Matce Bożej, Niepokalanów 1981, 40-43.

Hippolytus, Benedictiones Isaac et Iacob, PO 27, 6, 24, 76-78, tłum. W. Kania: Św. Hipolit Rzymski, Matka człowieka i Boga (z rozprawy ,O błogosławieństwach Patriarchów), w: Ojcowie Kościoła łacińscy. Teksty o Matce Bożej, Niepokalanów 1981, 28-29.

Hymni graeci in Ambrosium Mediolanensem, ed. G. Pasini: Le fonti greche su Sain'Ambrogio di Milano, SAEMO 24/1, Milano - Roma 1990, tłum. G. Jaśkiewicz: Wschód Zachodowi. Greckie hymny ku czci łacińskiego biskupa Ambrożego z Mediolanu, Lublin 2012.

IRENAeus, Adversus haereses, PG 7, 437-1224, thum. W. Myszor: Ireneusz z Lyonu i gnostycy. Zdemaskowanie i odparcie fatszywej gnozy. Thumaczenie Adversus haereses. Księga I i II, SACh SN 17, Katowice 2016; tłum. W. Kania: Św. Ireneusz, Przyczyna naszego zbawienia (fragment), w: Ojcowie Kościoła greccy i syryjscy. Teksty o Matce Bożej, Niepokalanów 1981, 24-25.

Iustinus, Apologia 1, ed. M. Marcovich, PTS 38, 1994, tłum. L. Misiarczyk: Justyn Męczennik, 1 Apologia, w: Justyn Męczennik, 1 i 2 Apologia. Dialog z Żydem Tryfonem, Warszawa 2012, 43-89; tłum. W. Kania: Św. Justyn, Oto Panna pocznie (fragment), w: Ojcowie Kościoła greccy i syryjscy. Teksty o Matce Bożej, Niepokalanów 1981, 23.

Origenes, Homiliae in Lucam, ed. H. Crouzel - F. Fornier - P. Perichon, SCh 87, Paris 1962, thum. S. Kalinkowski, Homilie o Ewangelii św. Łukasza, PSP 36, Warszawa 1986; tłum. W. Kania: Orygenes, Homilia na Nawiedzenie Najśw. Panny, Homilia na temat hymnu Magnificat, w: Ojcowie Kościoła greccy i syryjscy. Teksty o Matce Bożej, Niepokalanów 1981, 26-29, 30-32.

Romanus Melodus, Hymnus 35, ed. J. Grosdidier de Matons, SCh 128, Paris 1967, 160187, tłum. W. Kania: Roman Piewca, Maryja pod Krzyżem, w: Ojcowie Kościoła greccy i syryjscy. Teksty o Matce Bożej, Niepokalanów 1981, 110-116.

Sedulius Caelius, Epistula ad Macedonium, w: Sedulius Caelius, Opera omnia. Dzieła wszystkie. Tekst łacińsko-polski, tłum. H. Wójtowicz, Lublin 1999, 75-83.

Socrates Scholasticus, Historia ecclesiastica, PG 67, 29-842, thum. S. Kazikowski: Sokrates Scholastyk, Historia Kościoła, Warszawa 1972.

Tertullianus, Apologeticum, ed. E. Dekkers, CCL 1, Turnhout 1954, 78-171, Documenta Catholica Omnia, 0160-0220 Tertullianus, Apologeticum, LT, tłum. J. Sajdak, Apologetyk, POK 20, Poznań 1947.

Tertullianus, De carne Christi, ed. J.-P. Mahé, SCh 216, Paris 1975, 210-309, tłum. W. Eborowicz - W. Kania: Tertulian, O Ciele Chrystusa (fragment 1-23), w: Ojcowie Kościoła łacińscy. Teksty o Matce Bożej, Niepokalanów 1981, 17-27. 


\section{Literatura starożytna}

Hymni Homerici, panteon.pl/Hymny-homeryckie [tekst grecki i polski].

Hymni orphici, pantheon.pl/Hymny-do-Bogow-hellenskich\#orfickie [tekst grecki i polski]. Iosephus Flavius, Antiquitates Iudaicae, ed. B. Niese, Flavii Iosephi Opera, t. 1-4, Berlin 1885-1892, tłum. Z. Kubiak - J. Radożycki: Józef Flawiusz, Dawne dzieje Izraela, Poznań 1979.

\section{Opracowania}

AlÈs A. de., Dogme d'Ephèse, Paris 1931, 116-156.

Beck H.-G., Kirche und theologische Literatur im Byzantinishen Reich, München 1959.

Bотте B. Dom, Rites et familles liturgiques, w: L'Église en prière, éd. A.G. Martimort, Paris 1961, 15-33.

Capelle B. Dom, Les fêtes mariales, w: L’Église en prière, éd. A.G. Martimort, Paris $1961,747-765$.

Denis-Boulet N.M., Analyse des rites et des prières de la messe, w: L'Église en prière, éd. A.G. Martimort, Paris 1961, 325-343.

Grosdidier de Matons J., Recherches sur Romanos le Mélode et sur les origines de Kontakion, Paris 1961.

Haussing H.W., Historia kultury bizantyńskiej, tłum. T. Zabłudowski, Warszawa 1969.

JEANLIN F., Citations et thèmes bibliques dans l'hymn Acathiste (byzantine) à la Mère de Dieu, w: La Liturgie interprète de l'Ecriture, éd. C. Braga - A. Pistoia, Paris 2002, 89-103.

Krypiakiewicz P.F., De hymni Acathisti auctore, ByZ 18 (1909) 357-382.

KumanieCKi K., Historia kultury starożytnej Grecji i Rzymu, Warszawa 1967.

Langkammer H., Chrystologiczne hymny Nowego Testamentu. Najstarszy obraz Chrystusa, Katowice 1976.

Marrou H.-I., Histoire de l'éducation dans l'Antiquité, t. 1: Le monde grec, Paris 1948, reprint 2000.

Maryja w tajemnicy Chrystusa, red. C. Napiórkowski - S. Longosz, Niepokalanów 1997.

Meersseman G.G., Der Hymn Akathistos im Abendland, Freiburg 1958.

Morrisson C., La continuité de l'Empire Romain en Orient, w: Le monde byzantin, éd. C. Morrison, t. 1: L'Empire d'Orient, Paris 2004, 3-48.

Nadolski B., Troparion, w: Leksykon Liturgii, opr. B. Nadolski, Poznań 2006, 1632.

Nikolaou Th., Akathistos Hymnos, w: Marienlexikon, opr. R. Bäumer - L. Scheffczyk, Regensburg 1988, 66-67.

Peltoman L.M., The Image of the Virgin Mary in the Akathistos Hymn, Brill - Leiden Boston - Köln 2001.

RACHUTA R., Muzyka w Biblii, praca doktorska pod kierunkiem K. Ilskiego, miejsce i data nie są podane, pełny tekst pracy w: https:/repozytorium.amu, edu.pl.../1Praca\%doktorska20\%Robert\%20Rachuta.pdf (dostęp 10.02.2018).

Starowieyski M., Sobory Kościoła niepodzielonego, Tarnów 1994.

Suski A., Hymniczne cytaty Nowego Testamentu w świetle „Formgeschichte”, StPł 15 (1977) 7-22.

Testa E., The faith of the Mother Church, transl. P. Rotondi, Jerusalem 1992.

The Oxford Bible Commentary, ed. J. Barton - J. Muddiman, Oxford 2001.

The Oxford Dictionary of the Christian Church, red. L. F. Cross - E.A. Livingstone, Oxford 1997.

Toniolo E.M., Akathistos. Inno alla Madre di Dio. Edizione metrica. Mistagogia, Commento al testo, Roma 2017. 
VEREECKEN J., L'hymne Acathiste, Icône chantée et le mystère de l'Incarnation en nombres, „Byzantion” 63 (1993) 357-387.

WARE K., L'orthodoxie. L'Église des sept Conciles, transl. F. Lhoest, Paris 2002.

Wellesz E. A History of Byzantine Music and Hymnography, Oxford 1949, $1962^{2}$.

Wolosiuk W., Kontakion, EK IX 744.

WoźNIAK J., Recepcja „,Theotokos” u Ojców syryjskich, w: Maryja w tajemnicy Chrystu$s a$, red. C. Napiórkowski - S. Longosz, Niepokalanów 1997, 69-77.

Wysocki M., Autorstwo „Te Deum” w świetle współczesnych badań, „E-Patrologos” 1 (2015) z. 4, 50-59. 